\title{
HUNGARIAN NATIONAL REPORT ON IASPEI (2015-2018)
}

\author{
István Bondár , Attila Galsa**, Zoltán Gráczer*, Katalin Gribovszki*, \\ Erzsébet Győri*, János Kiss ${ }^{* * *}$, Márta Kiszely*, László Lenkey ${ }^{* *}$, Bálint Süle*, \\ Gyöngyvér Szanyi ${ }^{*}$ Ernö Takács ${ }^{* * *}$, Péter Varga*, Zoltán Wéber*
}

\section{Introduction}

The past four years saw major developments in the IASPEI community in Hungary. Organizational changes include the merger of the Geological and Geophysical Institute of Hungary and the Hungarian Office for Mining and Geology into the Mining and Geological Survey of Hungary in 2017. The AlpArray experiment, with the Research Center for Astronomy and Earth Sciences, Geodetic and Geohysical Institute (MTA CSFK GGI) Kövesligethy Radó Seismological Observatory of the Hungarian Academy of Sciences as a core member, began in late 2015. In Hungary, 14 temporary threecomponent broadband stations have been deployed for the AlpArray temporary seismic network between December 2015 and July 2016. The first infrasound array in Hungary began operations in June 2017.

\section{Observational seismology}

Varga (2016) summarized the history of the Seismological Observatory of Budapest from its foundation in 1905 to date. The MTA CSFK GGI Kövesligethy Radó Seismological Observatory is a member of the International Federation of Digital Seismograph Networks (FDSN, http://www.fdsn.org), the Observatories \& Research Facilities for European Seismology (ORFEUS, www.orfeus-eu.org), the International Seismological Centre (ISC, www.isc.ac.uk), the EuropeanMediterranean Seismological Center (EMSC, www.emsc-csem.org), and the Central and Eastern European Earthquake Research Network (CE3RN, http://www.ce3rn.eu) organizations as well as the AlpArray (http://www.alparray.ethz.ch) and the Atmospheric dynamics Research Infrastructure in Europe (ARISE, http://arise-project.eu) projects.

\subsection{The Hungarian National Seismological Network}

The MTA CSFK GGI Kövesligethy Radó Seismological Observatory operates the Hungarian National Seismological Network (HNSN, doi:10.14470/UH028726). The network has been significantly expanded with both permanent and temporary broadband stations since 2015. All HNSN stations are registered in the International Registry of Seismograph Stations, and the waveforms are archived at the GEOFON European Integrated Data Archive (EIDA) node (https://geofon.gfzpotsdam.de/doi/network/HU). Gráczer et al. (2018b) provides a detailed description of the HNSN permanent and temporary stations.

Between 2015 and 2018 two new permanent stations were added to the HNSN. KOVH (Kővágótöttös), equipped with a Streckeisen STS-2.5 seismometer and an Earthdata PS-6-24 digitizer, was deployed in southern Hungary in February 2015. ABAH (Abaújkér) was deployed in October 2016 and it is equipped with a Streckeisen STS-2.5 seismometer and a Guralp CMGDM24S3EAM data acquisition unit. The short period station CSKK (Csókakő) was upgraded to a broadband Guralp CMG-3T 120s seismometer in January 2016. Finally, a Guralp Radian borehole seismometer was installed at $70 \mathrm{~m}$ depth next to the AMBH (Ambrózfalva) station in November 2018.

The MTA CSFK GGI contributed to the AlpArray Seismic Network (Hetényi et al. 2018) with 11 broadband seismic stations deployed in Western Hungary. Three additional stations were provided by the Swiss-AlpArray SINERGIA program (two of them were dismantled in October 2017).

\footnotetext{
*Kövesligethy Radó Seismological Observatory, MTA CSFK Geodetic and Geophysical Institute E-mail: bondar.istvan@csfk.mta.hu ${ }^{* *}$ Department of Geophysics and Space Science, Eötvös Loránd University ${ }^{* * *}$ Mining and Geological Survey of Hungary
} 
The Hungarian AlpArray stations are equipped with Guralp CMG-3T 120s seismometers and Guralp DM24S3EAM digitizers, while the Swiss-AlpArray SINERGIA stations have Trillium Compact 120s sensors with Taurus 3 channel 24-bit digitizers.

All the HNSN waveforms are streamed to the Kövesligethy Radó Seismological Observatory. The automatic processing runs SeisComP3 (www.seiscomp3.org), and the automatic bulletins are published on the website, www.seismology.hu. Automatic e-mail alerts on earthquakes in Hungary are sent to the Hungarian National Directorate General for Disaster Management. Automatic event notifications are published on twitter (http://twitter.com/szeizmologia). The manual review is also carried out with SeisComP3. The final hypocenter parameters in the annual Hungarian National Seismological Bulletin (HNSB) are determined by $i L o c$, a further developed version of the ISC location algorithm (Bondár and Storchak 2011). Besides the hypocenter and phase data of natural and anthropogenic events occurred in Hungary and its surroundings, HNSB lists the focal mechanism of several earthquakes as well as the macroseismic data of felt earthquakes in Hungary (Gráczer et al. 2015, 2016, 2017, 2018a). The automatic bulletins are reported to the ISC in real time; the annual HNSB is sent to the ISC once it is published. The HNSB can be downloaded from the Kövesligethy Radó Seismological Observatory website (www.seismology.hu). iLoc, together with the RSTT global 3D velocity model (Myers et al. 2010) is available for download from the IRIS software depository, https://seiscode.iris.washington.edu/projects/iloc.

\subsection{The Hungarian National Infrasound Network}

The Hungarian National Infrasound Network (HNIN, doi:10.14470/UA114590) was established by the MTA CSFK Kövesligethy Radó Seismological Observatory with the deployment of the PSZI (Piszkés-tetö) infrasound array in 2017 (Czanik and Bondár 2017). The PSZI array is registered at the International Registry of Seismographic Stations, and waveforms are collected in real time at the GEOFON EIDA node (https://geofon.gfz-potsdam.de/doi/network/HN). The PSZI array is located in the Mátra Mountains. The array consists of four elements and has an aperture of approximately $300 \mathrm{~m}$. Each element of the array is equipped with a SeismoWave MB3d microbarometer with a built-in digitizer. The central element of the infrasound array is co-located with a permanent broadband seismological station, PSZ, jointly managed by the Kövesligethy Radó Seismological Observatory and the GFZ German Research Centre for Geosciences.

For data acquisition SeisComP3 (www.seiscomp3.org) and for infrasound data processing DTK$P M C C$ (Cansi, 1995) are used. Both programs are found in the CTBTO NDC-in-a-Box software package. The seismo-acoustic and infrasound-only events are located with iLoc (Bondár et al. 2018). The first Hungarian Seismo-Acoustic Bulletin has been published by the MTA CSFK Kövesligethy Radó Seismological Observatory early 2019 (http://infrasound.hu/pdf/HSAB20172018.pdf).

\section{Seismicity studies}

\subsection{Historical seismicity}

The knowledge of past earthquakes of the Pannonian Basin is rather incomplete. Between 1000 and 1750 , only about 200 significant events are known. Furthermore, up to the beginning of the 16th century, there are only five earthquakes with approximately known geographical locations. These are Savaria (Szombathely, Hungary, 455), Selmecbánya (Banská Štiavnica, Slovakia, 1441), Zólyomlipcse (Slovenská Lupča, Slovakia, 1443), Temesvár (Timişoara, Romania, 1443) and Szeged (Hungary, 1444). Based on historical sources, the magnitude of the earthquake in Savaria appears to be significantly above M6. However, according to our present knowledge, this area is completely aseismic (Varga 2017).

Two distinguished professors, Pál Kitaibel and Ádám Tomcsányi of the Royal University of Pest published a book on Mór earthquake (1810, M5.4) in 1814. The "Dissertatio de terrae motu Mórensi" contains a number of useful field observations, such as the appearance of faults, variations in the 
rate of spring water output, and water chemistry changes related to earthquake. Most notably, the book contains the first published isoseismal map in the world (Varga 2015a, Varga et al. 2015). Timár (2015) investigated the topographic base and georeference of the earthquake. Kiszely (2015) and Budai et al. (2018) determined the local seismic activity in the Vértes and Gerecse mountains.

\subsection{Recent seismicity}

Between 2013 June and 2015 January, 35 earthquakes with local magnitude ML ranging from 1.1 to 4.2 occurred in Nógrád county, Hungary. This earthquake sequence represents above average seismic activity in the region and is the first one that was recorded by a significant number of threecomponent digital seismographs in the county. Using the Bayesloc multiple-event location algorithm (Myers et al. 2007, 2009), Wéber (2016b) have estimated the hypocenters of 30 earthquakes with $\mathrm{ML} \geq 1.5$. The events occurred in two small regions of a few squared kilometers: one to the east of Érsekvadkert and the other at Iliny. The uncertainty of the epicenters is about $1.5-1.7 \mathrm{~km}$ in the E-W direction and 1.8-2.1 km in the N-S direction at the $95 \%$ confidence level. The estimated event depths are confined to the upper $3 \mathrm{~km}$ of the crust. Kiszely et al. (2016) performed waveform correlation on the two closest stations and a cluster analysis using the correlation coefficients.

One of the largest recent earthquake sequences (ML 4.5) hit near Oroszlány in central Hungary in 2011, with more than 200 aftershocks. The Oroszlány sequence is one of the best recorded event clusters to date in Hungary. Kiszely and Györi (2015) attempted to separate quarry blasts from the aftershock sequence using waveform correlation and cluster analysis. Békési et al. (2017) relocated the Oroszlány cluster with the double difference multiple event location algorithm (Waldhauser and Ellsworth 2000). The improved locations of the events allowed to identify a N-S striking, steeply eastward dipping fault plane, in agreement with the N-S striking nodal plane of the moment tensor solution of the main shock. Owing to the favorable network geometry and the accurate relative locations, 7 earthquakes were identified as ground-truth (Bondár et al. 2004, Bondár and. McLaughlin 2009a).

The largest earthquake in the past decade occurred near Tenk, Hungary on 22 April 2013. The ML 4.8 event had two smaller foreshocks and 27 aftershocks. Czecze et al. (2017) relocated the Tenk cluster with the double difference multiple event location algorithm (Waldhauser and Ellsworth, 2000). The best fitting plane to the new hypocenters shows a good agreement with the focal mechanism solutions (Wéber 2016a).

Kiszely et al. (2017) analysed events in the Mecsek mountains to determine the best method to separate earthquakes and quarry blasts relying on ground truth information from reports of mining captains. They concluded that the spectral properties and waveform similarities of seismograms can be used to revise the classification of events in the HNSB and some $16 \%$ of the events that were originally identified as earthquakes between 2004 and 2016 were actually quarry blasts.

Bondár et al. (2018) relocated the seismicity of the Pannonian Basin for the entire digital instrumental period between 1996 and 2016 using the state-of-the-art location algorithm, iLoc (Bondár and Storchak 2011, Bondár and McLaughlin 2009b, Bondár et al. 2015). The relative abundance of ground-truth (Bondár et al. 2004, Bondár and McLaughlin 2009a) events (324 quarry blasts and earthquakes) allowed us to evaluate the performance of the $1 \mathrm{D}$ local velocity models used in the past and the global 3D upper-mantle and crustal regional seismic travel time (RSTT, Myers et al. 2010) velocity models. They demonstrated that the RSTT model captures the major 3D velocity heterogeneities and provides an improved view of the seismicity in the region. Figure 1 shows the resulting seismicity map after the relocations. 


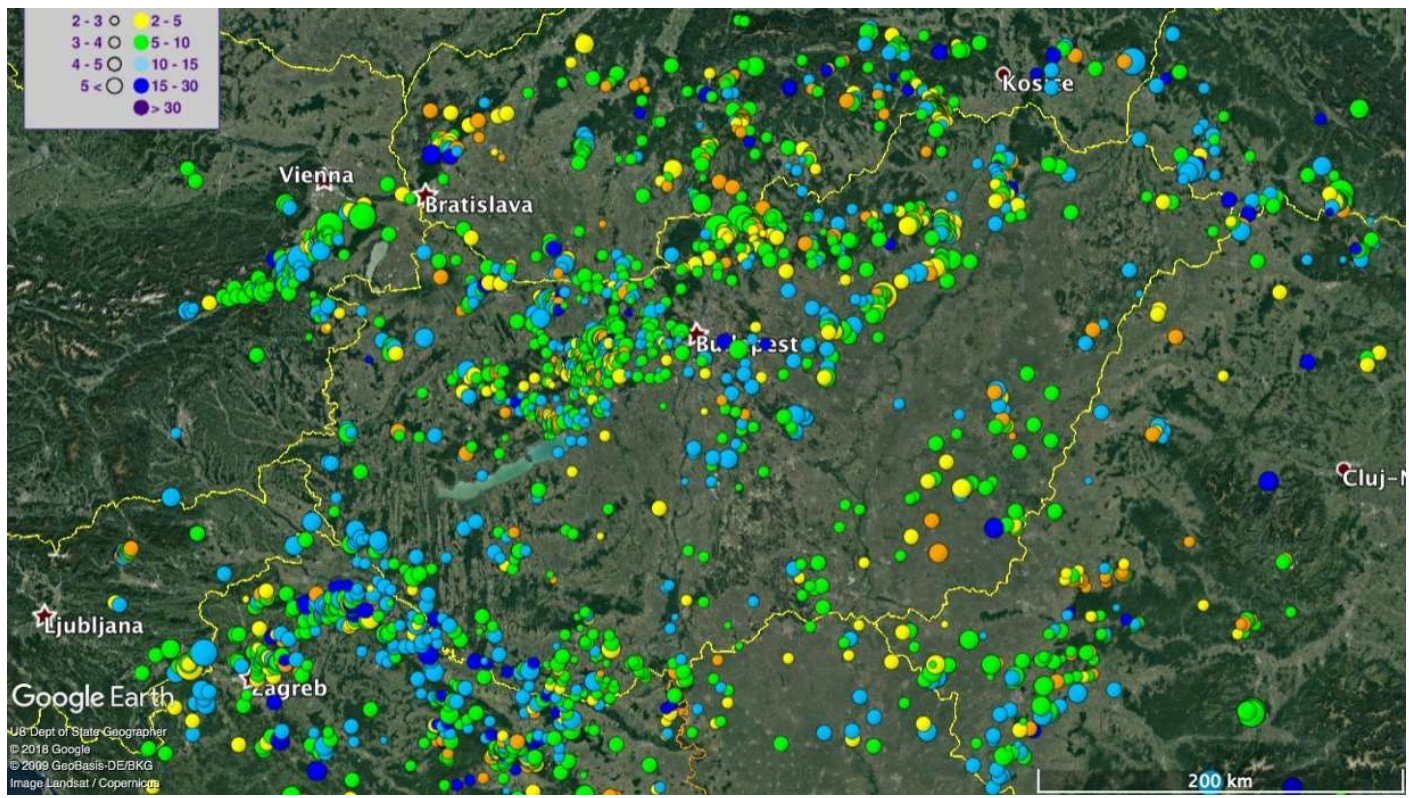

Figure 1. Seismicity of the Pannonian Basin relocated using the upper mantle and crust global 3D RSTT model. Known anthropogenic events are excluded from the map. Events are scaled by magnitude and color-coded by depth

Varga et al. (2017) studied the waveforms of one of largest of deep earthquakes, the May 24, 2013 Mw 8.3 event under the Sea of Okhotsk, recorded at the Russian and Hungarian seismological networks and concluded that event was preceded by an earthquake swarm that consisted of $58 \mathrm{M} \geq 5$ events that occurred between May 15 and 24, 2013 in the higher part of the sinking slab east of Kamchatka in an area of increased historical seismicity. The aftershock activity after the Okhotsk Sea earthquake was moderate: twelve events with magnitudes above M4 were observed till June 27. Although, in comparison with shallow events, the number of aftershocks is unusually small, these events determine a fault area of $2.64 \times 10^{4} \mathrm{~km}^{2}$.

\section{Earthquake hazard studies}

\subsection{Seismic microzonation}

Local geological conditions can considerably amplify damages occurring during earthquakes. To determine site amplification, numerous measurements were performed in Budapest, in connection with seismic hazard assessment and microzonation of the capital. The studied areas were delineated on the basis of different types of engineering geological maps, available geotechnical data and macroseismic intensities observed during the 1956 Dunaharaszti earthquake.

Microseismic noise measurements were performed to identify and delineate the areas where resonance of subsurface sedimentary layers can occur. Resonance frequencies and the strength of the resonance were determined by computing horizontal-to-vertical spectral ratio $(\mathrm{H} / \mathrm{V})$ curves. Beside average $\mathrm{H} / \mathrm{V}$ curves, their azimuthal variations were also computed.

Areas where soil resonance can occur during earthquakes have been found mainly in the valleys and hill-side areas in the Buda side. Strong resonance was found in some locations; in some cases, coincidence of soil and building resonance frequencies also occurred. Computing directivity, lateral amplification could be detected in some cases that originates from the inhomogeneous local geology and topography. Drawing the polarity diagrams onto a topographic map, amplification of topography moreover the effect of the valley edge could be also detected.

Microseismic noise measurements were performed in different types of buildings (brick and panel buildings with different number of floors) measuring the background noise in different levels 
of the building. Fundamental mode was determined from the peak on the H/V curve whose amplitude was increased with the floor number.

Active (MASW) and passive (ESAC, ReMi) seismic measurements based on the dispersion properties of surface waves were carried out in several locations to determine the $\mathrm{S}$ wave velocities in the near surface layers. The $\mathrm{S}$ wave velocity profiles have been computed by the joint inversion of complementary (MASW, ReMi, ESAC, H/V) measurements. At these places, local applicability of seismic interferometry was also studied. The method gave mixed results, its applicability mainly has depended on the distribution of noise sources.

Microseismic noise measurements were also performed to map the resonant frequencies of upper geological layers in the locality of Zlaté Hory, Northern Moravia. The cause of the significant harmonic vibrations that was recorded in the vicinity of the winding tower during its demolition was determined on the basis of resonant frequencies that were analysed together with the results of geophysical measurements and borehole documentation (Lednická et al. 2015).

\subsection{Small scale ambient seismic noise tomography at Dunaszekcső high bank}

High banks are prone to landslides, therefore passive measurements have to be used when studying them by seismic methods. As a pilot project, small scale ambient noise tomography was successfully applied at the Dunaszekcső high bank, where significant landslides occurred in the last decade. The aim of the study was to map near surface velocity anomalies since it is assumed that the formation of tension cracks which precedes landslides are represented by low velocity anomalies.

Szanyi et al. (2016) performed microseismic noise measurements at the top of the Castle Hill in October 2014 and June 2015 . The study area was chosen to be at the surroundings of presently active head scarp formed in April 2011. Phase cross-correlation and time-frequency phase weighted stacking were applied to calculate the cross-correlation functions that were used to retrieve the dispersion curves. A Rayleigh wave group velocity map was constructed for $0.1 \mathrm{~s}$ period. The average Rayleigh wave group velocity was found to be $171 \mathrm{~m} / \mathrm{s}$. The group velocity map revealed a region of negative velocity anomaly; its location coincided with a highly creviced area, where slope failure had taken place along a several metre-wide area. Another low velocity zone was also detected at a previously unknown weakened area. The noise source distribution was also studied and it was found that the most energetic noise is originated not from the Danube, but from the residential area of Dunaszekcső.

\subsection{Liquefaction hazard assessment}

Although the seismicity of Hungary is moderate, soil liquefaction have been observed and documented at least eight times during historical earthquakes in Hungary. Their surface manifestations were reported from Komárom (1763, 1783, 1822), Mór (1810), Érmellék (1829, 1834), Kecskemét (1911) and Dunaharaszti (1956) earthquakes. Győri et al. (2015) studied contemporary macroseismic observations that demonstrated the occurrence of soil liquefaction. Building or structural damage caused by the phenomenon is proven only in the case of 1763 Komárom earthquake. Local subsoil conditions and information regarding ground water level were also studied. Distributions of horizontal ground accelerations possibly caused by these historical earthquakes were modelled by ShakeMap. The ground accelerations simulations show horizontal PGA of $0.2-0.3 \mathrm{~g}$ in areas where liquefaction occurred.

Liquefaction and post-liquefaction settlement as a secondary earthquake effect are one of the main concerns during site characterization of major industrial/nuclear installations in Hungary. Katona et al. (2015) showed that the practicable empirical methods for definition of liquefaction susceptibility provide rather controversial results. Selection of method for assessment of soil behaviour that affects the integrity of structures requires specific considerations. The case of nuclear power plant at Paks, Hungary, was used as an example for demonstration of practical importance of the presented results and considerations. 
Significant part of epistemic uncertainties in evaluation of liquefaction potential arise from the application of different methods. In practice, the probability of liquefaction is usually determined using empirical correlations that are based one of the in situ measurements (SPT, CPT, shear wave velocity measurements). Bán et al. (2016) have developed an empirical method where the results of $\mathrm{CPT}$ and $\mathrm{V}_{\mathrm{S}}$ measurements are used in parallel. The two types of measurements can supplement each other and more and more frequently these are carried out in parallel. Bán et al. (2018) evaluated the prediction capability of the method on an independent dataset of the 2010-2011 Canterbury earthquake sequence and compared it with commonly used empirical procedures. It was found that the error index defined to quantify the false predictions is the largest for the recommended method but regarding the number of false predictions, it outperforms the other methods used for comparison.

\subsection{Speleoseismology}

Gribovszki et al. (2017a, 2017b) presented the result of a stalagmite-based case study from the Little Carpathians of Slovakia. A specially-shaped (candlestick type), intact and vulnerable stalagmite (IVSTM) in Plavecká priepast cave has been examined since 2013. This formation survived all earthquakes that have occurred over thousands of years, depending on the age of the stalagmite. This stalagmite is suitable for estimating the upper limit of horizontal peak ground acceleration generated by prehistoric earthquakes. Such type of stalagmites exists at many different caves in Earth.

The investigation consists of the following steps: (i) in-situ non-destructive determination of the natural frequencies, and measuring the dimensions of the IVSTM; (ii) laboratory measurements of the geomechanical and elastic properties of stalagmite samples; (iii) calculation of the natural frequencies of the IVSTM and the static horizontal ground acceleration value $\left(\mathrm{a}_{\mathrm{g}}\right)$, which would break the IVSTM; (iv) age determination of core samples taken from speleothems; (v) determination of seismic wave attenuation with depth; (vi) construction of a critical horizontal ground acceleration curve going back into the past.

Figure 2 presents the critical horizontal ground acceleration (HGA) value as a function of time determined from the stalagmite in the Plavecká Priepast cave. Gribovszki et al. (2017a, 2017b) compared the effect of the Jókö earthquake (1906) on the location of the Plavecká priepast cave to the critical horizontal ground acceleration value provided by the stalagmite we investigated and claimed that the effect of Jókő earthquake (1906) is consistent with the critical HGA value provided by the stalagmite. At the time of Jókö event (1906) the critical HGA value could not have been higher than $1 \mathrm{~m} / \mathrm{s}^{2}$, and $1.3 \mathrm{~m} / \mathrm{s}^{2}$ at the time of the assumed Carnuntum event ( $\sim 340$ A.D.).

The approach used in Gribovszki et al. (2017a, 2017b) yields significant new constraints on the seismic hazard, as tectonic structures close to Plavecká priepast cave did not generate strong earthquakes in the last few thousand years. The results of this study are highly relevant given that the two capitals, Vienna and Bratislava are located within 40 and $70 \mathrm{~km}$ of the cave, respectively.

The approach to determine to HGA by using stalagmites is very conservative. In order to get a more sophisticated threshold for HGA several different investigations are required, such as numerical and analogue modeling of the stalagmites' vibration and failure process; model computation for determining the depth-dependent attenuation of seismic waves above the cave, detailed investigation of geomechanical and elastic properties of stalagmites (Konečný et al. 2015). The pattern of oscillation of the investigated stalagmites should be fully understood as well since at the resonance frequency the stalagmites can break more easily than in the static case. During our cave observations we observed that the harmonic oscillations of the investigated stalagmites split into two parts. Therefore, Gribovszki et al. (2018) simulated the oscillation by setting up four simplified models of the stalagmites. The eigenfrequencies of the different stalagmite models have been calculated numerically, by the finite element method, and compared with the measured in situ values. The splitting of eigenfrequencies were reproduced by the numerical model calculations, taking into account the asymmetric shape of the stalagmite. 


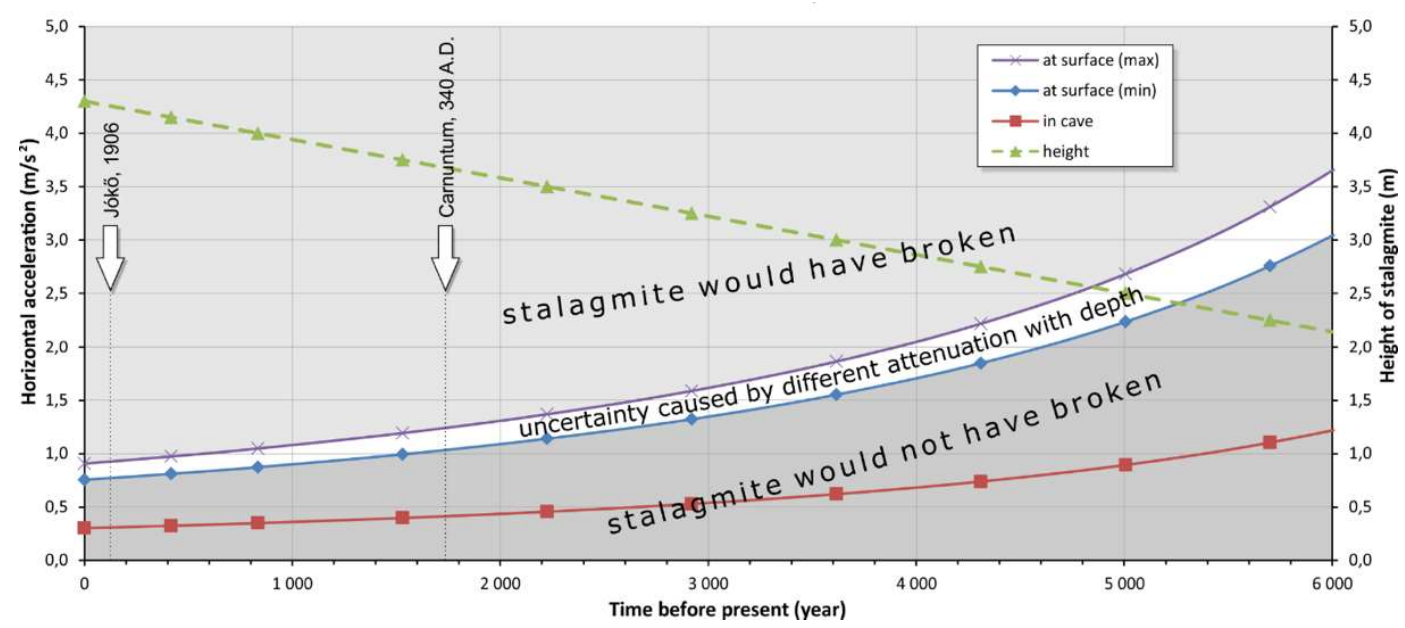

Figure 2. Constraint on critical horizontal ground acceleration at the surface (purple and blue curves) and in the cave (red curve) provided by the height of the investigated stalagmite (green line) as a linear function of time going back into the past. The arrows show the ages of the assumed and real moderate size or large earthquakes occurred in the past. The uncertainty of the critical HGA at the surface is given by the white region

\section{Earthquake source mechanism studies}

Wéber (2016a) has estimated the full moment tensors of 22 local earthquakes in Hungary with local magnitude ranging from 1.2 to 4.8 that occurred between 1995 and 2014 . The probabilistic waveform inversion procedure (Wéber 2006) takes into account the effect of the random noise contained in the seismograms, the uncertainty in the hypocenter and the inaccurate knowledge of the velocity structure, while estimating the error affecting the derived focal parameters. The probabilistic approach maps the posterior probability density functions for both the hypocentral coordinates and the moment tensor components. This waveform inversion method is equally suitable to recover the source mechanism for low-magnitude events using short-period local waveforms as well as for moderate-size earthquakes using long-period seismograms. Only strike-slip and thrust faulting events have been found, giving further support to the hypothesis that the Pannonian basin is currently experiencing a compressional regime of deformation. The orientations of the obtained focal mechanisms are in good agreement with the present-day stress field derived by Bada et al. (2007). The azimuth of the subhorizontal P principal axis varies from about NNE-SSW in SW Hungary through NE-SW well inside the basin to around E-W in the NE part of the country.

Wéber $(2006,2016 \mathrm{~b})$ estimated the full moment tensors of four earthquakes in the Nógrád sequence with $\mathrm{Mw} \geq 3.6$ using a probabilistic waveform inversion procedure. All of the analyzed earthquakes have strike-slip mechanism with either right-lateral slip on an approximately N-S striking or left-lateral movement on a roughly E-W striking nodal plane. Both the $\mathrm{P}$ and $\mathrm{T}$ principal axes are horizontal, and the $\mathrm{P}$ axis is oriented along a NE-SW direction.

Estimating the mechanisms of small $(\mathrm{M}<4)$ earthquakes is quite challenging. A common scenario is that neither the available polarity data alone nor the well predictable near-station seismograms alone are sufficient to obtain reliable focal mechanism solutions for weak events. To handle this situation, Wéber (2018) has developed a novel method that jointly inverts waveforms and polarity data following a probabilistic approach. The joint waveform and polarity (JOWAPO) inversion maps the posterior probability density of the model parameters and estimates the maximum likelihood double-couple mechanism, the optimal source depth and the scalar seismic moment of an event. The uncertainties of the solution are described by confidence regions. The method was validated on two earthquakes for which well-determined focal mechanisms are available. The validation tests demonstrated that including waveforms in the inversion considerably reduces the uncertainties of the usually poorly constrained polarity solutions. The JOWAPO method performs best when it 
applies waveforms from at least two seismic stations. If the number of the polarity data is large enough, even single-station JOWAPO inversion can produce acceptable solutions.

\section{Lithospheric studies}

\subsection{Deep seismic and geophysical potential field data}

The Geological and Geophysical Institute of Hungary and Hungarian Office for Mining and Geology were merged into Mining and Geological Survey of Hungary in 2017. However, the transformation did not cause any difficulties in the continuation of our lithospheric investigations. Several important results published in the last four years are summarized below.

To refine the geological model of southeast Hungary, we reprocessed historical data of the international Pannonian Geotraverse program as well as reflection data along five additional profiles, recently made available by the oil and gas industry. During the data reprocessing, we aimed to preserve the true seismic amplitudes. To perform reliable depth imaging, we applied pre-stack depth migration (PSDM). Figure 3 shows a presumed magmatic intrusion under the Derecske Trough. Furthermore, the spatial orientation of two master faults intersecting the whole crust with different origins was determined. The first one is dipping towards northeast beneath the Makó Trough and the Battonya High, and the strike of the other one is near parallel with the Szolnok Flysch Belt. The Moho depth map of the study area was also significantly refined (Gúthy et al. 2018).

The CELEBRATION 2000 large-scale refraction experiment covered a significant part of eight Central European countries, and provided substantial coverage for a subsequent $3 \mathrm{D}$ velocity tomography over approximately a $100 \times 150 \mathrm{~km}$ area in northeast Hungary. The area was located between the eastern rim of the Mátra Mountains and the eastern border of the Nyírség region, the penetration of the inversion was about $10 \mathrm{~km}$. By means of the velocity tomography a batholite-like formation was detected under the Mátra Mountains (Figure 4), and three other well defined volcanic bodies were observed beneath the Nyírség area.

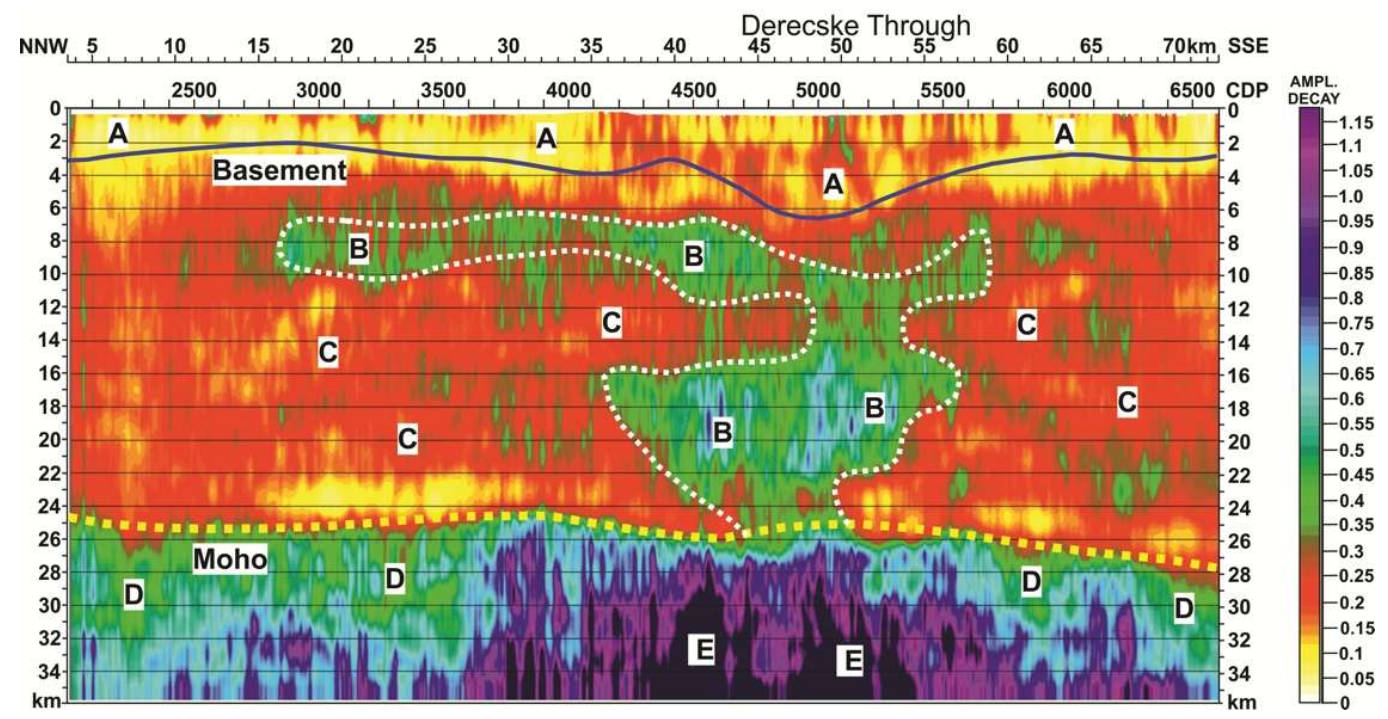

Figure 3. Presumable magmatic intrusion under the Derecske Trough based on the reflection energy decay. (A) Sedimentary and metasedimentary formations, (B) Magmatic intrusion, (C) Older crustal portions, (D) Uppermost transitional part of the mantle, (E) Supposedly higher temperature mantle material 


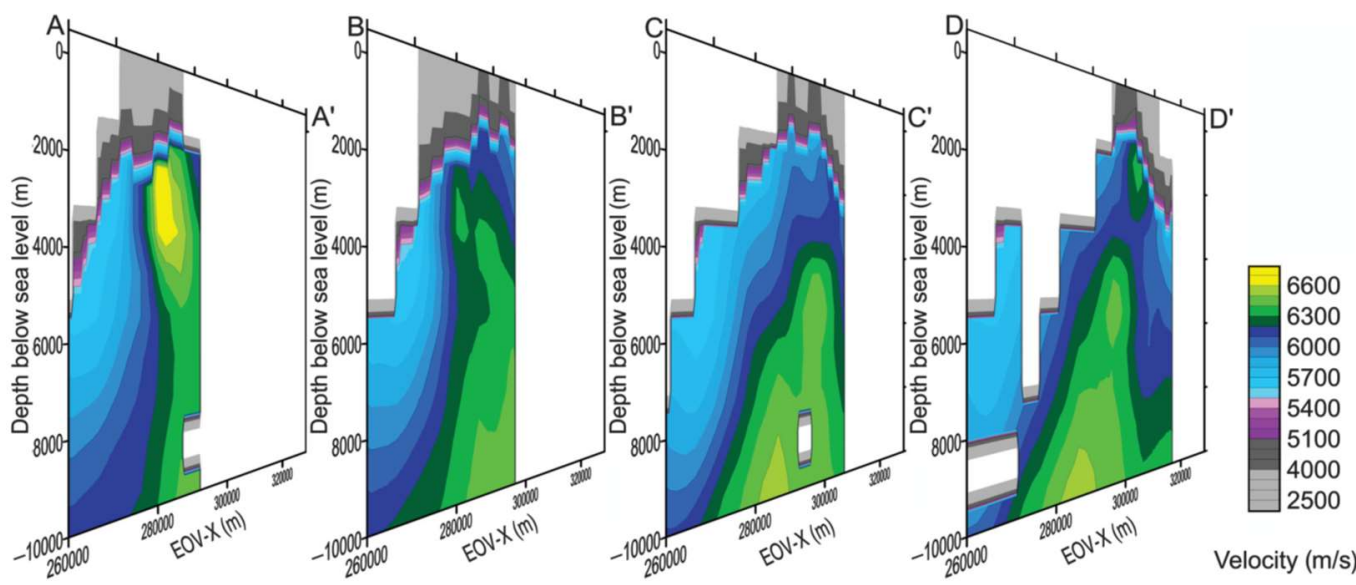

Figure 4. Velocity slices obtained from 3D refraction tomography beneath the Mátra Mountains showing a high-velocity anomaly $(6.3-6.7 \mathrm{~km} / \mathrm{s})$. The anomaly might be due to the batholithic source of the volcanic material

Kiss and Bodoky (2015) performed an integrated interpretation on the available geophysical potential field and deep seismic data to understand the lithospheric processes forming the CarpathianPannonian region. Kiss (2016) interpreted gravity and magnetic anomalies together with the seismic data to identify regional faults, deep structures, and shear zones. Kiss (2017) studied the effect of isostasy, including regional isostasy, using the "parachute model" beneath the region.

Kiss et al. (2015), applying Airy's isostatic model, defined the surface of the Moho beneath Hungary. Figure 5 shows that the map corresponds well with the data obtained from deep seismic surveys; however, it provides a much denser spatial coverage. The new surface map enabled to compensate the gravity impact of the Moho, preserving only the effects of the density variations in the upper crust. That has a great importance in the surface geological investigations and in determination of the depth of basement.

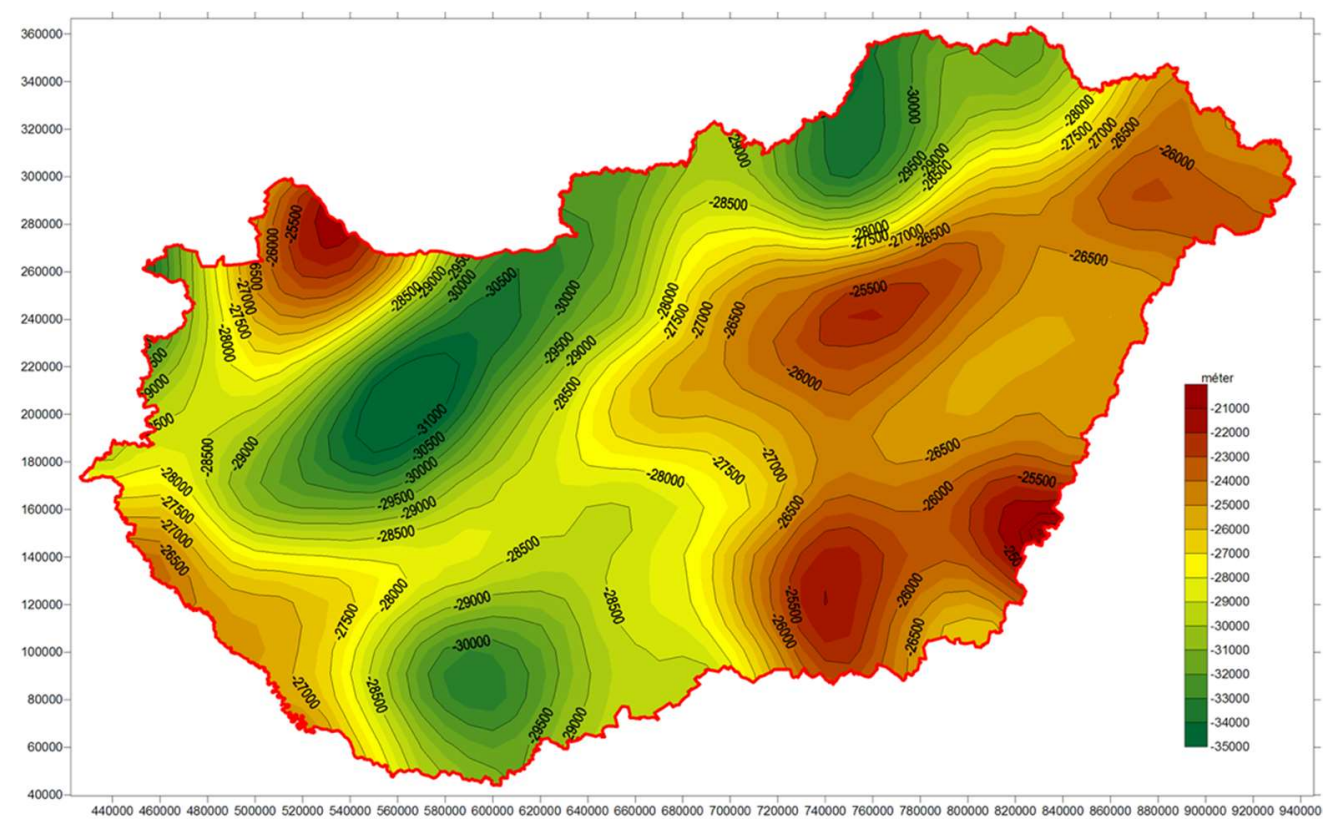

Figure 5. Moho depth map beneath Hungary calculated using Airy's isostatic model 
We also studied the regional, low amplitude anomaly zones of the national geomagnetic map (Figure 6). Based on borehole data, the lithological sources of the anomalies could be identified only partially, because their sources are usually located deeper than the bottom of the holes (Kiss 2015). However, the deep refraction profiles of the CELEBRATION 2000 experiment permitted to examine the global lithospheric structure beneath Hungary (Kiss et al. 2017). The regional velocity models obtained by seismic refraction tomography indicated several high velocity intrusions, with a velocity range of the lower crust, in the upper crust. Almost all of the velocity anomalies are correlated with high magnetic features (Figure 7). Those magnetic lineaments demonstrate the global fabric of the subsurface of Hungary, and are in a good correlation with the regional faults, main shear zones, and often with the Moho surface (Kiss 2016). Finally, Kiss and Prácser (2016) and Kiss et al. (2017) implemented magnetic body detection by Naudy deconvolution along the deep refraction profiles that lead to new results to locate buried intermediate and mafic formations (Figure 8).

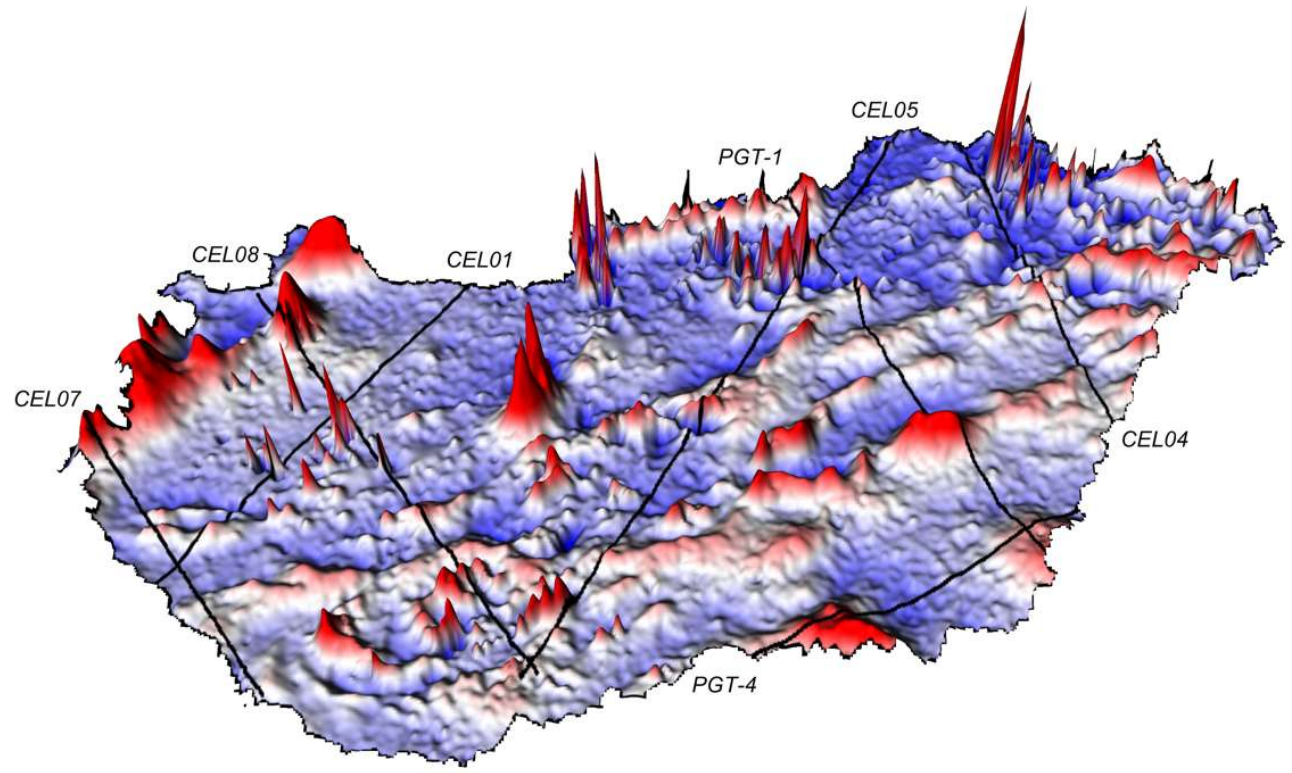

Figure 6. Magnetic anomaly map of Hungary showing the CELEBRATION 2000 deep refraction profiles

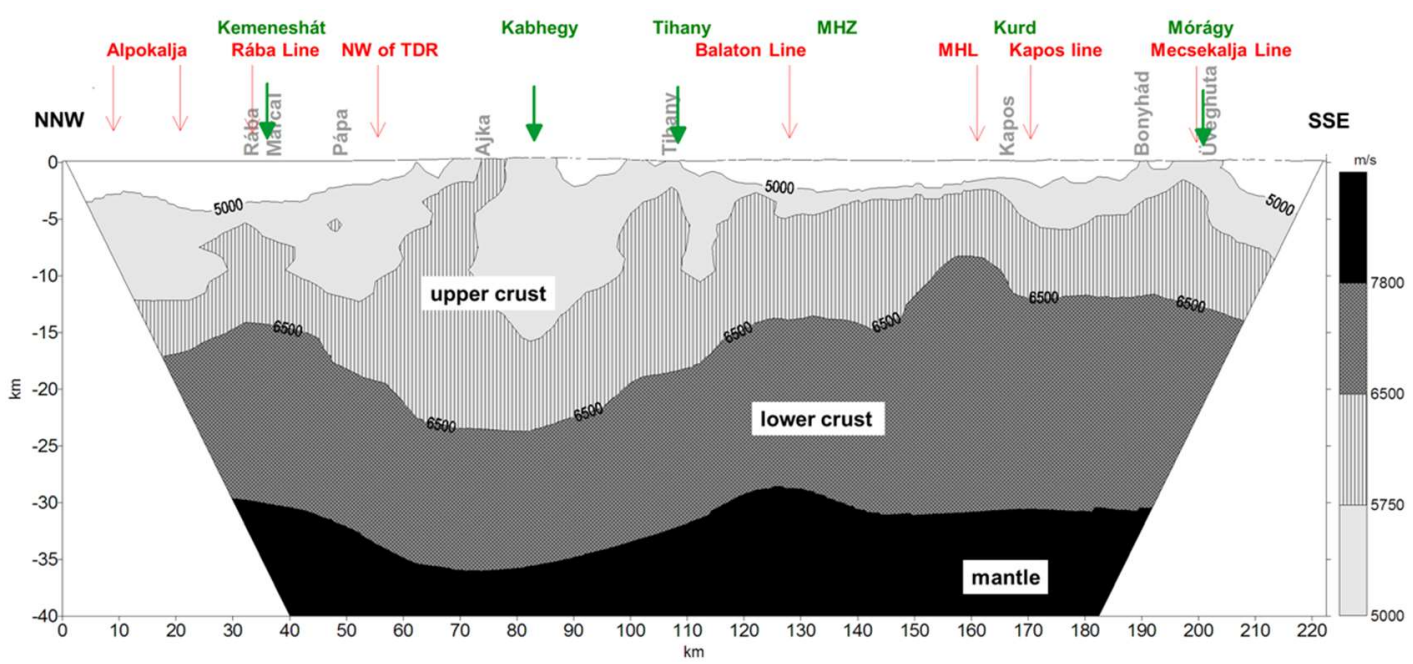

Figure 7. Crustal structure based on the CEL08 lithospheric velocity section obtained by seismic refraction tomography 


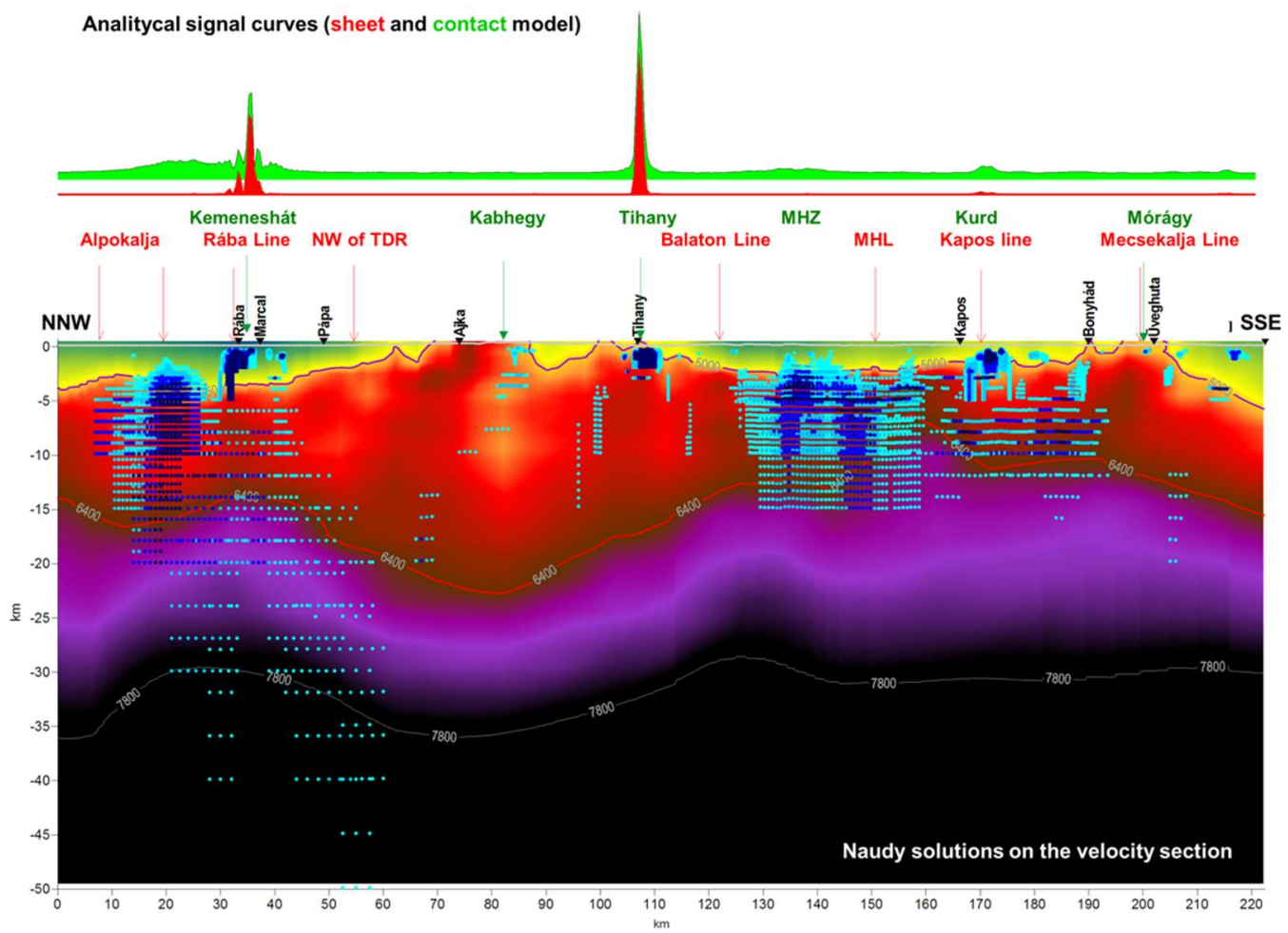

Figure 8. CEL08 lithospheric velocity section displaying the results of the magnetic body detection (below) and computed magnetic gradient curves for sheet and contact models (above)

\subsection{Receiver function analysis and ambient noise tomography}

Kalmár et al. (2018) performed P receiver function analysis for the West Pannonian Basin. The unprecedented station density owing to the AlpArray network allowed us to map the Moho depth in great details.

Szanyi (2016) performed ambient noise tomography for Hungary. Fundamental mode Rayleigh wave group velocity maps were prepared with a spatial resolution of around $70 \mathrm{~km}$ for the periods 7-26 s for almost the whole territory of the country. First, a four-layer, average $\mathrm{S}$ wave velocity profile was created for the region. According to this $1 \mathrm{D}$ model, the average basin depth is $3 \mathrm{~km}$ and the thickness of the upper and lower crust is 8 and $16 \mathrm{~km}$, respectively. The average $\mathrm{S}$ wave velocity in the crustal layers are $2.34 \mathrm{~km} / \mathrm{s}, 3.10 \mathrm{~km} / \mathrm{s}$ and $3.53 \mathrm{~km} / \mathrm{s}$, respectively, while in the uppermost mantle it can be estimated as $4.16 \mathrm{~km} / \mathrm{s}$. Then a three-dimensional $\mathrm{S}$ wave velocity structure of the Pannonian basin was computed down to the depth of approximately $35 \mathrm{~km}$.

\subsection{Thermal modeling}

During the report period we carried out thermal modeling of the lithosphere of the Alp-CarpathianPannonian regions. The Pannonian basin is characterized by high heat flow density of $80-120 \mathrm{~mW} / \mathrm{m}^{2}$ and elevated geothermal gradient of $40-50{ }^{\circ} \mathrm{C} / \mathrm{km}$. The $200{ }^{\circ} \mathrm{C}$ isotherm is situated in $4 \mathrm{~km}$ depth or less, which makes the basin favorable for deep geothermal exploration. In order to reveal the deep thermal conditions we carried out conductive heat transport modelling.

Lenkey et al. (2017) developed a three-layer model consisting of Tertiary sediments, underlying crust and lithospheric mantle in the Alpine-Pannonian transition zone including the Vienna, Danube, Styrian and the Mura-Zala basins. The crust and mantle were homogenous with constant thermal properties, and the thermal conductivity of sediments varied horizontally and vertically based 
on laboratory measurements. The area underwent lithospheric stretching during the Early-Middle Miocene time (Horváth 1993), therefore the 3D time-dependent conductive heat transport equation was solved. We calculated the initial temperature distribution in the lithosphere at the end of rifting using non-homogeneous stretching factors (Lenkey 1999), and we modeled the present-day thermal field. The results of the model fit to the observed heat flow density and temperatures, except in those areas where intensive groundwater flow occurs in the carbonatic basement of the Transdanubian Range and Northern Calcareous Alps, and the metamorphic basement high between the Mura trough and Styrian basin.

Békési et al. (2018) constructed a similar 3D conductive thermal model for Hungary. The model consists of six sedimentary layers, upper crust, lower crust, and lithospheric mantle, where each layer has its own thermal properties. The prior thermal properties and basal condition of the model is updated through the ensemble smoother with multiple data assimilation technique. The model is able to reproduce the thermal effect of lithospheric extension and sediment infill of the Pannonian basin. Results suggest that the hottest areas below $3 \mathrm{~km}$ are linked to the basement highs surrounded by deep sub-basins of the Great Hungarian Plain.

In contrast to the Pannonian basin the Transylvanian basin has an anomalously low heat flow density of 30-40 mW/m² (Demetrescu et al. 2001). 2D lithospheric scale heat flow modelling, simulating the present-day thermal regime of the basin shows the great importance of paleoclimate and sedimentation during the evolution of the basin. Heat flow densities corrected for these processes are $20 \%$ higher compared with observed heat flow. The modelling implies that the low values of heat flow density are the result of a combination of thermal effects of Middle - Upper Miocene sedimentation and the presence of ophiolitic rocks, depleted in radioactive isotopes, located in the basin basement (Tiliţă et al. 2018).

Kovács et al. (2017) put up the hypothesis that the depths for the lithosphere-asthenosphere boundary (LAB) and the mid-lithospheric discontinuities (MLD) evolve because the upper mantle contains pargasitic amphibole. The dehydration solidus of the pargasitic amphibole may result in a very small degree of partial melting in the upper mantle at temperatures in excess of $1050^{\circ} \mathrm{C}$ (for geochemically more depleted) or $1100{ }^{\circ} \mathrm{C}$ (for geochemically less depleted upper mantle) within the depth range from 30 to $90 \mathrm{~km}$. The partial melt may be responsible for changes in geophysical properties (e.g. lower seismic velocity, higher attenuation of seismic waves, higher electrical conductivity) attributed to the LAB and MLD. This simple petrologic model was tested using geophysical data of the Carpathian-Pannonian region (CPR). Geotherms in the lithosphere were calculated using Royden and Keen's (1980) non-homogeneous stretching model in the basin in a grid with $5 \mathrm{~km}$ spacing, and the depths to intersection of the geotherms with the dehydration solidus temperatures (1050 and $1100{ }^{\circ} \mathrm{C}$ isotherms) were obtained. The depth of the intersection agrees with the geophysically determined LAB in the central area of the CPR with an error of $5 \mathrm{~km}$. The good fit to the observations supports the hypothesis that the dehydration solidus determines the depth of the $\mathrm{LAB}$ in young continental rift areas. Towards the basin margins, where the heat flow is lower $\left(70 \mathrm{~mW} / \mathrm{m}^{2}\right)$, the predictive capability of the dehydration solidus model deteriorates. This is because, for lower geothermal gradients, pargasitic amphibole breaks down at $90 \mathrm{~km}$ before temperature exceeds the dehydration solidus temperatures.

\section{Mantle plumes}

Süle (2015) performed 3D numerical calculations to investigate the effect of Rayleigh number and temperature- and depth-dependent viscosity on the radius and temperature anomaly of mantle plumes and on surface observable characteristics such as topography and geoid anomaly. Depthdependent models were chosen, then the addition of weak and stronger temperature-dependence was studied. The Rayleigh number changed between $10^{5}$ and $10^{7}$. If viscosity decreases with temperature the convection becomes more vigorous and thermally weaker plumes rise from the bottom boundary layer. The radius and temperature anomaly of the upwelling decreases with increasing temperaturedependence. Topographic uplift significantly decreases with increasing temperature-dependence. For weak depth-dependent models the geoid decreases together with the topography as Rayleigh 
number increases. However, strongly depth-dependent models show negative geoid anomaly above the hot plume. In case of temperature- and depth dependent models the geoid have a maximum in the function of Rayleigh number. The amplitudes of topographic uplift in the case of stronger temperature-dependence and high Rayleigh number are not far from the observed values, but the geoid signal is higher by a factor of about 2 .

Galsa et al. (2015) investigated numerically the process of thermo-chemical mixing in the Earth's mantle in a 2D cylindrical shell domain. A new parameter, the effective buoyancy ratio was defined to quantify the evolution of a primordial dense layer around the core-mantle boundary. It was established that the effective buoyancy ratio, $B_{\text {eff }}$ decreases monotonically with time due to four physical processes: (1) warming of the deep, compositionally dense layer, (2) cooling of the overlying mantle, (3) eroding of the dense layer through thermal convection in the overlying mantle and (4) diluting of the dense layer through inner convection. When the value of $B_{\text {eff }}$ reaches 1 , the instability point (when stabilizing chemical and destabilizing thermal buoyancy is balanced) the pattern of the flow system changes considerably; the two-layer convection is replaced with a one-layer thermo-chemical mixing. The time of $B_{e f f}=0$ defines the time when the two layers are mixed. Larger initial density difference between the dense layer and the overlying mantle, $\beta$ results in more resistive dense layer and delays the occurrence of the thermo-chemical mixing and homogenization. Figure 9 illustrates the effect of $\beta$ on the evolution of the deep dense layer. When the initial density difference is $\beta=0.5 \%, 600 \mathrm{Myr}$ is enough to mix the two layers. But in the case of $\beta=2 \%$, the dense layer is more resistant, two-layer convection can slightly deform the surface of the dense layer. Nevertheless, the phase of the effective thermo-chemical mixing and homogenization occurred in each calculation. Although, for large values of $\beta(\beta>6 \%)$, this time exceeded the age of the Earth.
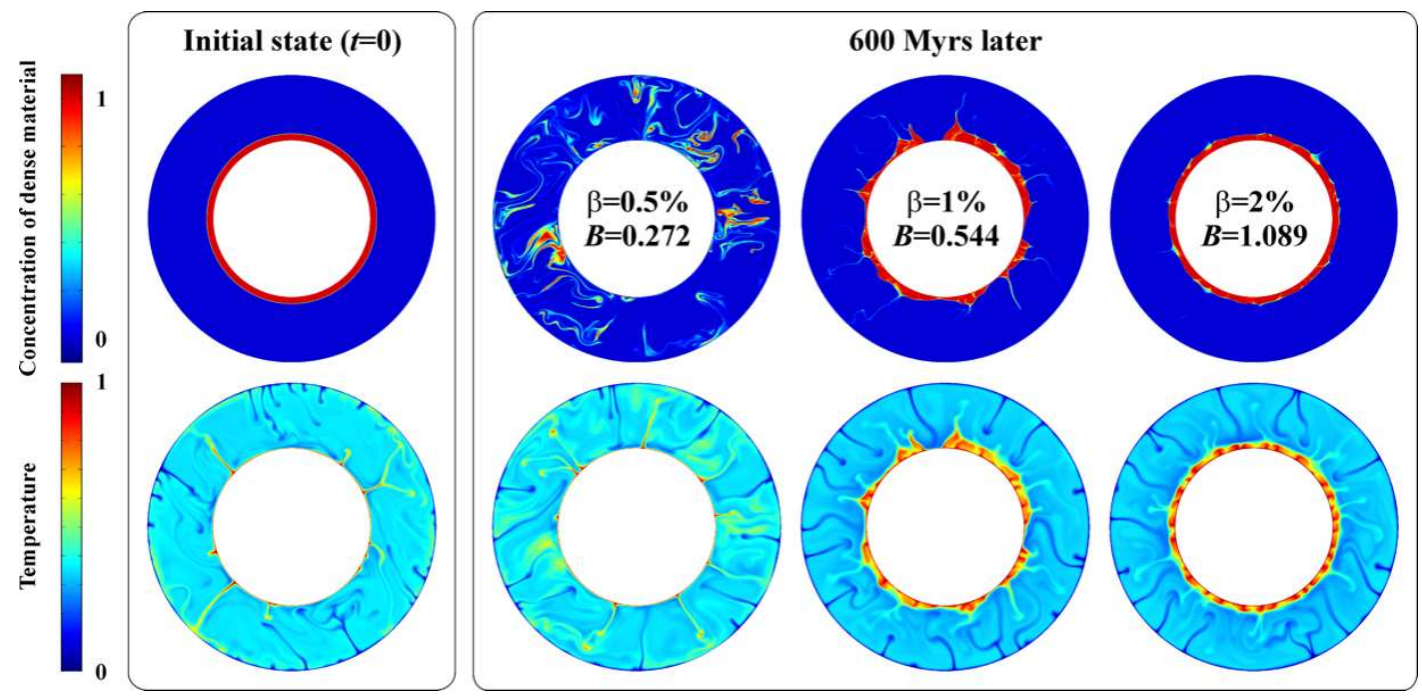

Figure 9. The non-dimensional concentration of the dense material and the temperature at the initial stage $(t=0)$ and 600 Myrs later at different initial compositionally density contrast between the dense layer and the overlying mantle $(\beta)$. $B$ denotes the buoyancy ratio in its classical meaning (Davaille et al. 1999)

Bozóki et al. (2017) carried out numerical model calculations to study the effect of the centrifugal force on the compositionally dense material accumulated in the lowermost mantle. The deformation of an initial dense layer encircling the core was investigated systematically as a function of the density difference between the lower dense and the overlaying mantle, $\beta$ and the angular velocity of the planet, $\Omega$ in a two-dimensional cylindrical shell domain. It was established that increasing $\beta$ does not influence the magnitude of the deformation of the dense layer but decreases the velocity of the deformation. The relaxation time of the deformation is inversely proportional to $\beta$ similarly to postglacial rebound. On the other hand, increasing $\Omega$ enhances the magnitude of the deformation but does not affect the deformation relaxation time. The magnitude of the deformation is approximately proportional to $\Omega^{2}$. It was pointed out that for the present-day mantle parameters, $\beta=2-4 \%$ and 
$\Omega=7.3 \cdot 10^{-5} 1 / \mathrm{s}$ the equatorial elevation of the dense layer is about $2 \mathrm{~km}$ which more than two orders of magnitude less than the height of the seismically observed large low shear velocity provinces beneath Africa and Pacific (e.g. Garnero et al. 2007).

\section{Geodynamic studies}

Schreider et al. $(2015,2016)$ and Varga $(2015 b)$ reconstructed the movement of the virtual dipole moment (VDM) of the earth's magnetic field through the Paleoarchean-Phanerozoic. The VDM change over time is characterized by a positive linear trend in the interval of $4.1 \times 10^{22} \mathrm{Am}^{2}(3.5 \mathrm{Ga}$ ago) to $5.5 \times 10^{22} \mathrm{Am}^{2}$ (to date). This background linear growth of the field strength is complicated by irregularly distributed VDM variations ranging in the amplitude from $1.7 \times 10^{22}$ to $3.7 \times 10^{22} \mathrm{Am}^{2}$ with the wavelength varying from 220 to $920 \mathrm{Ma}$. The average wavelength of such fluctuations is estimated to be $570 \mathrm{Ma}$, which is approximately equal by duration to the Wilson geological cycles. The interval of $0.84-1.3 \mathrm{Ga}$ before present is first established to be characterized by the relatively calm VDM region of 4.7-4.9 $\times 10^{22} \mathrm{Am}^{2}$. The first defined deep minimum with the extremum of $2.3 \times 10^{22} \mathrm{Am}^{2}(2.15 \mathrm{Ga}$ ago $)$ corresponds to the terminal phase in the formation of the Earth's core geometry and initiation of the formation of the modern dipole field.

There are various equations that describe relations between different classes of Love-Shida numbers. Varga et al. (2018) obtained an integral relation with the use of the time-varying gravitational potential, which connects tidal Love-Shida numbers, load numbers, and potential-free LoveShida numbers generated by normal and horizontal stresses. Varga et al. (2018) obtained the equations without any considerations concerning the boundary conditions at the surface and centre of the Earth. Therefore, they are valid both for tidal, load and potential free Love-Shida numbers. Furthermore, they do not follow from the sixth-order differential equation system of motion that are usually applied to calculate the Love-Shida numbers, and they can used in stress calculations both at the surface and within the Earth's mantle.

Varga and Grafarend (2018) calculated the lunisolar stress tensor in terms of their components along the latitude of the spherical surface of the Earth as well as inside the Earth (up to the coremantle boundary) for the PREM. Results of calculations prove that increase of stress as a function of depth reaching a value around some $\mathrm{kPa}$ at the depth of $900-1500 \mathrm{~km}$, well below the zone of deep earthquakes. At the depth of the overwhelming part of seismic energy accumulation (around $50 \mathrm{~km})$ the stresses of lunisolar origin are only $(0.0-1.0) \cdot 10^{3} \mathrm{~Pa}$. Despite the fact that these values are much smaller than the earthquake stress drops (1-30 MPa) they do not exclude the possible impact of tidal forces on outbreak of seismic events. Since the tidal potential and its derivatives are coordinate dependent and the zonal, tesseral and sectorial tides have different distributions from the surface down to the CMB, the lunisolar stress cannot influence the break-out of every seismological event in the same degree. The influencing lunisolar effect of the solid earth tides on earthquake occurrences is connected with its radial stress components acting parallel to the surface of the Earth. The influence of load tides is limited to the loaded area and its immediate vicinity.

The distribution of great earthquakes $(M \geq 7.0)$ and their released seismic energy along the Earth radius is asymmetric, as $90 \%$ of energy release occurs relatively close to the Earth's surface. The vast majority of the remaining $10 \%$ is associated with seismic events that occur at great depths. These very deep earthquakes (depth $\geq 350 \mathrm{~km}$ ) differ significantly from the shallow events, their source, in contrast to the shallow focus events, is located inside the plate. Varga et al. (2017) examined seven source zones of deep events, and showed that (except for one, Honsu-Kamchatka where both shallow and deep $M \geq 7.0$ earthquakes occur) linear distribution of deep earthquakes is considerably shorter than that found for the shallow earthquakes, which determine the length of the zone. In case of two further zones of deep earthquakes (Solomon Islands and Izu-Bonin-Mariana arc) there are no seismic events $M \geq 7.0$ deeper than $450 \mathrm{~km}$, where the aforementioned shortening occurs. For the remaining four zones (Indonesia, Philippines, Tonga-Kermadec and Chile-Peru) the length of shortening at the top of the lower mantle relative to the length of zone observed close to the surface unequivocal. Their emergence, as demonstrated by the spatial distribution of hypocenters, is controlled not only by slab stagnation but also by their penetration into the lower mantle 
influenced by the Venturi effect. The position of very deep ( $\geq 500 \mathrm{~km})$ earthquakes foci indicate where the downgoing lithospheric plates conflict with the upper boundary of lower mantle, and where they in some cases cross it. This passage generates compression - elongation inside the slab. A comparison of temporal distribution of shallow and deep seismic events suggests that there is no direct relationship in the distribution of these two different earthquake activities.

\section{References}

Bada G, Horváth F, Dövényi P, Szafián P, Windhoffer G, Cloetingh S (2007): Present-day stress field and tectonic inversion in the Pannonian basin. Glob. Planet. Change, 58, 165-180.

Bán Z, Mahler A, Katona TJ, Györi E (2016): Liquefaction assessment based on combined use of CPT and shear wave velocity measurement. In: Barry, M Lehane; Hugo, E Acosta-Martínez; Richard, Kelly (eds.) Geotechnical and Geophysical Site Characterisation, 5, Australian Geomechanics Society, 597-602.

Bán Z, Mahler A, Győri E (2018): Performance of liquefaction assessment method based on combined use of cone penetration testing and shear wave velocity measurement. ce/papers, 2(2-3), 193-198.

Békési E, Süle B, Lenkey L, Lenkey Á, Bogér I, Bondár I (2017): Double-difference relocation of the 29 January 2011 ML 4.5 Oroszlány earthquake and its aftershocks and its relevance to the rheology of the lithosphere and geothermal prospectivity. Acta Geod. Geophys., 52, 229-242, doi:10.1007/s40328-017-0195-7.

Békési E, Lenkey L, Limberger J, Porkoláb K, Balázs A, Bonté D, Vrijlandt M, Horváth F, Cloetingh S, van Wees JD (2018): Lithospheric-scale subsurface temperature model of the Hungarian part of the Pannonian Basin. Glob. and Planet. Change, 171, 48-64.

Bondár I, Myers SC, Engdahl ER, Bergman EA (2004): Epicenter accuracy based on seismic network criteria. Geophys. J. Int., 156, 483-496, doi: 10.1111/j.1365-246X.2004.02070.x.

Bondár I, McLaughlin K (2009a): A new ground truth data set for seismic studies. Seism. Res. Let., 80, 465-472, doi:10.1785/gssrl.80.3.465.

Bondár I, McLaughlin K (2009b): Seismic location bias and uncertainty in the presence of correlated and non-Gaussian travel-time errors. Bull. Seism. Soc. Am., 99, 172-193, doi:10.1785/0120080922

Bondár I, Storchak D (2011): Improved location procedures at the International Seismological Centre. Geophys. J. Int., $186,1220-1244$.

Bondár I, Engdahl ER, Villasenor A, Harris J, Storchak D (2015): ISC-GEM: Global instrumental earthquake catalogue (1900-2009), II. Location and seismicity patterns. Phys. Earth. Planet. Int., 239, 2-13, doi:10.1016/j.pepi.2014.06.002.

Bondár I, Mónus P, Czanik Cs, Kiszely M, Gráczer Z, Wéber Z, and the AlpArrayWorking Group (2018): Relocation of Seismicity in the Pannonian Basin Using a Global 3D Velocity Model. Seism. Res. Let., 89, 2284-2293, doi:10.1785/0220180143.

Bozóki T, Herein M, Galsa A (2017): Numerical evolution of the asymmetry in the compositionally inhomogeneous lower mantle driven by Earth's rotation. Acta Geod. Geophys., 52, 331-343.

Budai T, Fodor L, Sztanó O, Kercsmár Z, Császár G, Csillag G, Gál N, Kele S, Kiszely M, Selmeczi I, Babinszki E, Thamóné Bozsó E, Lantos Z (2018): Geology of the Gerecse Mountains, Explanatory book to the geological map of the Gerecse Mountains (1:50 000) (edited Budai T). Mining and Geological Survey of Hungary, Budapest.

Cansi Y (1995): An automated seismic event processing for detection and location: The P.M.C.C. method. Geophys. Res. Lett., 22, 1021-1024.

Czanik Cs, Bondár I (2017): The First Infrasound Array in Hungary. CTBT: Science and Technology Conference: Book of Abstracts, p. 9., 26-30 June 2017, Vienna, Austria.

Czecze B, Süle B, Bondár I (2017): A 2013. évi Heves megyei földrengéssorozat helymeghatározása többeseményes algoritmussal (Multiple event relocation of the 22 April 2013, ML = 4.8 Tenk (Hungary) earthquake aftershocks). in Hungarian, Magyar Geofizika, 58, 162-174.

Davaille A, Girard F, Le Bars M (2002): How to anchor hotspots in a convecting mantle? Earth Planet. Sci. Lett., 203, 621634.

Demetrescu C, Nielsen SB, Enea M, Şerban DZ, Polonic G, Andreescu M, Pop A, Balling N (2001): Lithosphere thermal structure and evolution of the Transylvanian Depression - insights from new geothermal measurements and modelling results. Phys. Earth Planet. Int., 126, 249-267.

Galsa A, Herein M, Lenkey L, Farkas MP, Taller G (2015): Effective buoyancy ratio: A new parameter for characterizing thermo-chemical mixing in the Earth's mantle. Solid Earth, 6, 93-100.

Garnero EJ, Lay T, McNamara A (2007): Implication of lower-mantle structural heterogeneity for existence and nature of whole-mantle plumes. Geol. Soc. Am. Spec. Pap., 430, 79-101.

Gráczer Z (ed.), Bondár I, Czanik Cs, Czifra T, Győri E, Kiszely M, Mónus P, Süle B, Szanyi Gy, Tóth L, Varga P, Wesztergom V, Wéber Z (2015): Hungarian National Seismological Bulletin 2014. Kövesligethy Radó Seismological Observatory, MTA CSFK GGI, Budapest, p. 563.

Gráczer Z (ed.), Bondár I, Czanik Cs, Czifra T, Győri E, Kiszely M, Mónus P, Süle B, Szanyi Gy, Szúcs E, Tóth L, Varga P, Wesztergom V, Wéber Z (2016): Hungarian National Seismological Bulletin 2015. Kövesligethy Radó Seismological Observatory, MTA CSFK GGI, Budapest, p. 278. 
Gráczer Z (ed.), Bondár I, Czanik Cs, Czifra T, Győri E, Kiszely M, Mónus P, Süle B, Szanyi Gy, Szücs E, Tóth L, Varga P, Wesztergom V, Wéber Z (2017): Hungarian National Seismological Bulletin 2016. Kövesligethy Radó Seismological Observatory, MTA CSFK GGI, Budapest, p. 353.

Gráczer Z (ed.), Bondár I, Czanik Cs, Czifra T, Győri E, Kiszely M, Mónus P, Süle B, Szanyi Gy, Tóth L, Varga P, Wesztergom V, Wéber Z (2018): Hungarian National Seismological Bulletin 2017. Kövesligethy Radó Seismological Observatory, MTA CSFK GGI, Budapest.

Gráczer Z, Szanyi G, Bondár I, Czanik Cs, Czifra T, Győri E, Hetényi Gy, Kovács I, Molinari I, Süle B, Szucs E, Wesztergom V, Wéber $\mathbf{Z}$ and AlpArray Working Group (2018): AlpArray in Hungary: temporary and permanent seismological networks in the transition zone between the Eastern Alps and the Pannonian basin. Acta Geod. Geophys., 53, 221-245, https://doi.org/10.1007/s40328-018-0213-4

Gribovszki K, Kovács K, Mónus P, Bokelmann G, Konecny P, Lednická M, Moseley G, Spötl C, Edwards RL, Bednárik M, Brimich L, Tóth L (2017a): Estimating the upper limit of prehistoric peak ground acceleration using an in-situ, intact and vulnerable stalagmite from Plavecká priepast cave (Detrekői-zsomboly), Little Carpathians, Slovakia - first results. J. Seismol., 21(5), 1111-1130, doi: 10.1007/s10950-017-9655-3.

Gribovszki K, Kovács K, Mónus P, Bokelmann G, Konecny P, Lednická M, Moseley G, Edwards, RL, Spötl C, Bednárik M, Brimich L, Hegymegi E, Tóth L, Kegyes-Brassai Cs, Szeidovitz Gy (2017b): Contraints on long-term seismic hazard from vulnerable stalagmite in Plavecká priepast cave, Slovakia (in Hungarian). Magyar Geofizika, 58(1), 1-16.

Gribovszki K, Esterhazy S, Bokelmann G (2018): Numerical modeling of stalagmite vibration. Pure Appl. Geophys., 175(12), 4501-4514, doi: 10.1007/s00024-018-1952-4.

Gúthy T, Takács E, Kovács ACs, Fancsik T, Csabafi R, Török I, Hegedűs E (2018): Recent developments in imaging the earth's crust by deep seismic data beneath the eastern parts of the Pannonian Basin Interpretation. 6(1), SB23-SB35, doi: 10.1190/INT-2016-0206.1.

Győri E, Tóth L, Mónus P (2015): Secondary effects generated by earthquakes: liquefaction occurrences in and around Hungary. Acta Geod. Geoph. Hung., 50(1), 79-95.

Hetényi Gy, Molinari I, Clinton J, Bokelmann G, Bondár I, Crawford WC, Dessa JX, Doubre C, Friederich W, Fuchs F, Giardini D, Gráczer Z, Handy MR, Herak M, Jia Y, Kissling E, Kopp H, Korn M, Margheriti L, Meier T, Mucciarelli M, Paul A, Pesaresi D, Piromallo C, Plenefisch T, Plomerová J, Ritter J, Rümpker G, Sipka V, Spallarossa D, Thomas C, Tilmann F, Wassermann J, Weber M, Wéber Z, Wesztergom V, Zivcic M, AlpArray Seismic Network Team, AlpArray OBS Cruise Crew, AlpArray Working Group (2018): The AlpArray Seismic Network: A Large-Scale European Experiment to Image the Alpine Orogen. Surv. Geophys., 39, 10091033, doi: 10.1007/s10712-018-9472-4.

Horváth F (1993): Towards a mechanical model for the formation of the Pannonian basin. Tectonophysics, 226, 333-357.

Kalmár D, Süle B, Bondár I, AlpArray Working Group (2018): Preliminary Moho depth determination from receiver function analysis using AlpArray stations in Hungary. Acta Geod. Geophys., 53, 309-321, doi: 10.1007/s40328-0180218-z

Katona TJ, Bán Z, Győri E, Tóth L, Mahler A (2015): Safety Assessment of Nuclear Power Plants for Liquefaction Consequences. Science and Technology of Nuclear Installations. Paper: 727291.

Kiss J (2015): Connection between geomagnetic anomalies and map of geological formations penetrated by wells in the Pannonian Basin (in Hungarian). Magyar Geofizika, 56(1), 21-42.

Kiss J, Bodoky T (2015): What starts and what is driving subductions of lithospheric plates (in Hungarian)? Magyar Geofizika, 56(4), 197-208.

Kiss J, Gúthy T, Zilahi-Sebess L (2015): Research of the Mohorovičić discontinuity in Hungary (methods, measurements and results (in Hungarian). Magyar Geofizika, 56(3), 152-178.

Kiss J, Vértesy L, Gulyás Á, Madarasi A (2015): TISIA - in the mirror of geophysics. in Hungarian, Abstract Book of TISIA conference, 25-28, ISBN 978-963-8221-56-8.

Kiss J (2016): Comprehensive interpretation of gravity and magnetic anomalies in Carpathian-Pannonian Region (in Hungarian). Földtani Közlöny, 146(3), 275-298.

Kiss J, Prácser E (2016): Data processing along a profile - semi-automated source detection, frequency filtering and depth slicing (CEL08 profile (in Hungarian). Magyar Geofizika, 57(2), 69-87.

Kiss J, Vértesy L, Gulyás Á (2017): Geomagnetic case studies from the Balaton Highland, the Danube-Tisza interfluve and the Tokaj Mountains (in Hungarian). Magyar Geofizika, 57(4), 126-151.

Kiss J (2017): An alternative model for the development of the Carpathian Basin and its environment (in Hungarian). Magyar Geofizika, 58(2), 66-75.

Kiss J, Vértesy L, Fancsik T, Kovács ACs, Madarasi A, Gulyás Á (2017): Tisia - in the light of geophysics and the interpretation of high seismic velocity zones in the crust (in Hungarian). Magyar Geofizika, 58(4), 209-229.

Kiszely M (2015): Earthquakes in Vértes-What Happens below our Feet (in Hungarian)? Magyar Tudomány, 3, 298-310.

Kiszely M, Győri E (2015): Separation of quarry blasts from the aftershock sequence of the Oroszlány (Hungary) January 29, 2011. Acta Geod. Geophys., 50, 97-107.

Kiszely M, Mónus P, Tóth L, Győri E (2016): Cluster analysis of earthquakes occurred in Érsekvadkert, Iliny Heves, between 2013 and 2015 (in Hungarian). Magyar Geofizika, 57(1), 35-46.

Kiszely M, Mónus P, Kalocsai L, Süle B, Győri E, Tóth L (2017): Revision of the Hungarian earthquake catalogs for seismic events occurred in the vicinity of the Mecsek Hill (in Hungarian). Magyar Geofizika, 58(3), 151-162.

Konečný P, Lednická M, Souček K, Staš L, Kubina L, Gribovszki K (2015): Determination of dynamic young's modulus of vulnerable speleothems. Acta Mont. Slov., 20(2), 156-163. 
Kovács I, Lenkey L, Green DH, Fancsik T, Falus Gy, Kiss J, Orosz L, Angyal J, Vikor Zs (2017): The role of pargasitic amphibole in the formation of major geophysical discontinuities in the shallow upper mantle. Acta Geod. Geophys., 52(2), 183-204.

Lednická M, Kaláb Z, Győri E (2015): Mapping the resonant frequencies of upper geological layers in the vicinity of abandoned mining pit at the Zlaté Hory locality, Northern Moravia. Acta Geodyn. Geomat., 12(2), 157-167.

Lenkey L, Raáb D, Goetzl G, Lapanje A, Nádor A, Rajver D, Rotár-Szalkai Á, Svasta J, Zekiri F (2017): Lithospheric scale 3D thermal model of the Alpine-Pannonian transition zone. Acta Geod. Geophys., 52(2), 161-182.

Lenkey L (1999): Geothermics of the Pannonian Basin and its bearing on the tectonics of basin evolution. Vrije Universiteit Amsterdam, p. 215.

Myers SC, Johannesson G, Hanley W (2007): A Bayesian hierarchical method for multiple-event seismic location. Geophys. J. Int., 171, 1049-1063.

Myers SC, Johannesson G, Hanley W (2009): Incorporation of probabilistic seismic phase labels into a Bayesian multipleevent seismic locator. Geophys. J. Int,, 177, 193-204.

Myers SC, Begnaud ML, Ballard S, Pasyanos ME, Phillips WS, Ramirez AL, Antolik MS, Hutchenson KD, Dwyer JJ, Rowe CA, Wagner GS (2010): A crust and upper-mantle model for Eurasia and North Africa for Pn travel-time calculation. Bull. Seism. Soc. Am., 100, 640-656.

Royden L, Keen CE (1980): Rifting process and thermal evolution of the continental margin of Eastern Canada determined from subsidence curves. Earth Planet. Sci. Let., 51, 343-361.

Schreider AA, Schreider AlA, Varga P, Denis C (2015): Evolution of the virtual dipole moment through the Paleoarchean-Phanerozoic. Oceanology, 55(2), 245-252.

Schreider AA, Ignatova AA, Schreider AIA, Sajneva AA, Varga P, Denis C (2016): Evolution of the virtual dipole moment calculation for reconstruction of the oceanic inversion magnetic layer parameters. Oceanology, 56(3), 463470 .

Süle B (2015): Mantle plume characteristics in three-dimensional depth- and temperature-dependent models. Acta Geod. Geophys., 50, 403-417.

Szanyi Gy (2016): A Pannon-medence S-hullám-sebességterének vizsgálata. PhD thesis, Eötvös Loránd Tudományegyetem, Budapest, p. 135., doi:10.15476/ELTE.2016.118

Szanyi Gy, Gráczer Z, Győri E, Kaláb Z, Lednická M (2016): Ambient Seismic Noise Tomography of a Loess High Bank at Dunaszekcső (Hungary). Pure Appl. Geophys., 173(8), 2913-2928.

Tiliță M, Lenkey L, Mațenco L, Horváth F, Surányi G, Cloetingh S (2018): Heat flow modelling in the Transylvanian basin: implications for the evolution of the intra-Carpathians area. Global Planet. Change, 171, 148-166.

Timár G (2015): Topographic Base and Georeference of Kitaibel's and Tomcsányi’s 1810 Mór Earthquake Map. in Hungarian, Magyar Tudomány, 3, 289-297.

Varga P (2015a): Bicentenary of Kitaibel's and Tomcsányi’s Book on the 1810 Mór Earthquake. in Hungarian, Magyar Tudomány, 3, 276-288.

Varga P (2015b): Long-term variations of the gravitational potential and of the geodynamical properties of a deformable Earth due to axial despinning. Leibniz Online, 19, 1-8.

Varga P, Timár G, Kiszely M (2015): Two Hundred Years Ago the Dissertatio de terrae motu Mórensi and the First Isoseismal Map Appeared. Seism. Res. Lett., 86(5), 1432-1437, doi: 10.1785/0220150076

Varga P (2016): From the Earthquake Observatory to the Radó Kövesligethy Seismological Observatory. in Hungarian, Ma-gyar Tudomány, 10, 1192-1217.

Varga P (2017): Old Hungarian earthquakes, with particular regard to Budapest. in Hungarian, Magyar Geofizika, 58(2), 76-87.

Varga P, Rogozhin EA, Süle B, Andreeva NV (2017): A Study of the Energy Released by Great (M $\geq 7)$ Deep Focus Seismic Events with Allowance for the Mw 8.3 Earthquake of May 24, 2013 in the Sea of Okhotsk, Russia. Phys. Solid Earth, 53(3), 385-409.

Varga P, Grafarend E, Engels J (2018): Relation of Different Type Love-Shida Numbers Determined with the Use of Time-Varying Incremental Gravitational Potential. Pure Appl. Geophys., 175, 1643-1648.

Varga P, Grafarend E (2018): Influence of Tidal Forces on the Triggering of Seismic Events. Pure Appl. Geophys., 175, 1649-1657.

Waldhauser F, Ellsworth WL (2000): A double-difference earthquake location algorithm: method and application to the northern Hayward fault, California. Bull. Seism. Soc. Am., 90, 1353-1368.

Wéber Z (2006): Probabilistic local waveform inversion for moment tensor and hypocentral location. Geophys. J. Int., 165, 607-621.

Wéber Z (2016a): Probabilistic waveform inversion for 22 earthquake moment tensors in Hungary: new constraints on the tectonic stress pattern inside the Pannonian basin. Geophys. J. Int., 204, 236-249.

Wéber Z (2016b): Source parameters for the 2013-2015 earthquake sequence in Nógrád county, Hungary. J. Seismol., 20, 987-999.

Wéber Z (2018): Probabilistic joint inversion of waveforms and polarity data for double-couple focal mechanisms of local earthquakes. Geophys. J. Int., 213, 1586-1598. 